\title{
PENINGKATAN KESEJAHTERAAN EKONOMI DESA MELALUI OPTIMALISASI PENGELOLAAN BUMDES BUDIDAYA LELE DI DESA PATEAN KECAMATAN BATUAN
}

\author{
Ita Rahmania Kusumawati ${ }^{*}$ \\ Mohammad Hidayaturrahman ${ }^{2}$ \\ Rovi Dani ${ }^{3}$ \\ 1Universitas Hasyim Asy'ari, Indonesia \\ 2,3Universitas Wiraraja, Indonesia \\ ita.jombang@yahoo.com ${ }^{1 *}$ \\ hidayaturrahman@wiraraja.ac.id ${ }^{1)}$
}

Kata Kunci: [BUMDes, Sosialisasi, FGD, Pendampingan]

\begin{abstract}
Abstrak: Kegiatan pengabdian kepada masyarakat ini bertujuan untuk memberikan pendampingan bagi pengelolaan BUMDes budidaya lele Al-Barokah di desa Patean Kecamatan Batuan kabupaten Sumenep. Target khusus yang diharapkan dari kegiatan ini adalah memberikan pemahaman dan keterampilan mengelola BUMDes bagi para pengelola BUMDes Al-Barokah, pemuda karang taruna, dan ibu-ibu PKK. Kegiatan ini dilakukan selama dua bulan, yang terdiri atas kegiatan sosialisasi, FGD, dan pendampingan dalam menyusun laporan keuangan melalui Microsoft Excel. Hasil kegiatan pengabdian ini adalah terbentuknya peluang bisnis aneka kuliner olahan lele pada kelompok PKK, terwujudnya laporan keuangan BUMDES budi daya lele secara digital (computerized), dan inovasi pengelolaan BUMDes budidaya lele yang meningkat secara perlahan namun signifikan, sehingga membantu akses ekonomi masyakarat.
\end{abstract}

Published by:

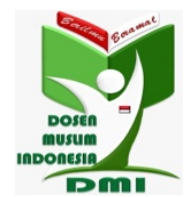

Copyright (C) 2021 The Author(s)

This article is licensed under CC BY 4.0 License (cc) $\mathrm{BY}$ 


\section{Pendahuluan}

Program BUMDES sesungguhnya memiliki peran yang strategis dalam pembangunan dan pemberdayaan masyarakat desa (Wahyuningtyas, 2021). Dengan mengusung semangat gotong royong, program BUMDES tidak hanya memberikan keuntungan berupa pembangunan dalam aspek fisik, tetapi juga keuntungan dalam aspek sosial (Firdaus, 2020). Menurut Peraturan Menteri Dalam Negeri Nomor 39 Tahun 2010, BUMDES merupakan usaha desa yang dibentuk atau didirikan oleh pemerintah desa dimana kepemilikan modal dan pengelolaannya dilaksanakan oleh pemerintah desa dan masyarakatnya (Yudiardi et al., 2020). Tujuan dari dibentuknya BUMDES merupakan upaya pemerintah untuk meningkatkan pendapatan masyarakat dan desa melalui berbagai kegiatan usaha ekonomi mereka. Keberadaan BUMDES ini juga diperkuat oleh UU Nomor 6 Tahun 2014 yang di bahas dalam BAB X pasal 87-90 yang antara lain menyebutkan bahwa pendirian BUMDES disepakati melalui musyawarah desa dan dikelola dengan semangat kekeluargaan dan kegotongroyongan (Dwiningwarni \& Amrulloh, 2020).

BUMDes juga merupakan instrumen pendayagunaan ekonomi lokal dengan berbagai jenis ragam potensi yang bertujuan untuk meningkatkan kesejahteraan ekonomi warga desa melalui pengembangan usaha ekonomi mereka (Yudiardi et al., 2020). Memperhatikan beberapa hal tersebut di atas, maka pada tanggal 28 Juli 2015, warga Desa Patean mendirikan Badan Usaha Milik Desa atau yang sering disebut BUMDes dan diberi nama "Al-Barokah". Dengan didirikannya BUMDes Al-barokah tersebut, masyarakat diharapkan mampu memanfaatkan potensi dan aset desa untuk membangun kesejahteraan melalui partisipasi dengan tujuan untuk mensejahterakan ekonomi desa. Namun dilihat dari faktanya, di dalam pelaksanaan BUMDes masih perlu dukungan serta partisipasi masyarakat untuk ikut serta dalam pengelolaannya, karena sebenarnya BUMDes ditujukan kepada masyarakat untuk dapat memberikan sumbangsih bagi peningkatan sumber pendapatan asli desa yang memungkinkan desa mampu melaksanakan pembangunan dan peningkatan kesejahteraan rakyatnya secara optimal (Puspaningrum \& Kurniawati, 2019).

Studi tentang pembangunan ekonomi dikenal sebagai ekonomi pembangunan. Pembangunan ekonomi mencakup proses dan kebijakan yang diterapkan negara untuk memperbaiki ekonomi, politik, dan kesejahteraan sosial warga negara atau penduduknya. Pembangunan desa sebagaimana dimaksud mengedepankan kebersamaan, kekeluargaan, dan kegotongroyongan guna mewujudkan perdamaian dan keadilan sosial (Dwiningwarni \& Amrulloh, 2020). Oleh sebab itu, dapat diketahui bahwa suatu perencanaan pembangunan, khususnya perencanaan pembangunan desa, sangat membutuhkan pendekatan yang menyeluruh (Pradana \& Ma'ruf, 2021). Perencanaan pembangunan desa merupakan perencanaan pembangunan yang dilakukan dari dan untuk masyarakat desa sendiri, dengan pengarahan, bimbingan, bantuan, dan pembinaan serta pengawasan yang dilakukan oleh pemerintah atau pihak terkait lainnya

Pembangunan berbasis masyarakat dalam bentuk Badan Usaha Milik Desa (BUMDes) diartikan sebagai tindakan partisipasi, yaitu tindakan untuk "mengambil bagian", atau pernyataan untuk mengambil bagian dari kegiatan dengan maksud untuk memperoleh manfaat (Srirejeki et al., 2020). Sedangkan dalam kamus Sosiologi disebutkan bahwa partisipasi merupakan keikutsertaan seseorang di dalam kelompok sosial untuk mengambil bagian dari kegiatan-kegiatan masyarakatnya, di luar pekerjaan atau profesinya sendiri (Friscilla et al., 2020). Konsep teori partisipasi mengemukakan 
tentang empat macam kegiatan partisipasi masyarakat yaitu: Partisipasi dalam pengambilan keputusan; 2. Partisipasi dalam pelaksanaan kegiatan; 3. Partisipasi dalam pemantauan dan evaluasi pembangunan; 4. Partisipasi dalam pemanfaatan hasil pembangunan (Larasati, 2019).

Terwujudnya kesejahteraan ekonomi desa dapat terimplementasi melalui dukungan pengelolaan yang optimal dari organisasi-organisasi yang bergerak di dalamnya (Puspaningrum \& Kurniawati, 2019). Organisasi ekonomi desa saat ini menjadi salah satu bagian penting yang penyokong titik lemah kondisi desa tersebut. Kesejahteraan ekonomi desa sangat memerlukan upaya sistematis untuk mendorong pengelolaan aset yang strategis dan mengembangkan jaringannya melalui peningkatkan daya saing ekonomi (Raka et al., 2018). Dalam konteks demikian, BUMDes menjadi salah satu upaya dan wujud konsolidasi atau penguatan terhadap lembaga-lembaga ekonomi desa (Srirejeki et al., 2020). Oleh sebab itu, di antara agenda yang bisa dilakukan oleh tim Abdimas antara lain adalah memberikan pendampingan dalam optimalisasi pengelolaan SDM sehingga mampu memberikan nilai tambah dalam menguatkan kelembagaan ekonomi desa dan pengelolaan aset ekonomi desa.

Namun jika yang terjadi adalah sebaliknya, yaitu minimnya pengetahuan tentang pengelolaan BUMDes dan kurangnya dukungan warga dan organisasi lainnya, sehingga menyebabkan menurunnya kesejahteraan ekonomi desa dan tidak terdukungnya titik lemah kondisi desa tersebut, maka diperlukan upaya sistematis untuk mendorong pengelolaan aset yang strategis dan peningkatkan daya saing ekonomi. Kurangnya keterampilan mengelola BUMDes dan minimnya dukungan masyarakat terhadap pengelolaan BUMDes tentu akan berdampak bagi kesejahteraan masyarakat desa secara umum. Masalah yang kemudian muncul adalah budaya migrasi atau urbanisasi akibat kurangnya keterampilan dalam mengelola potensi yang tekah ada sebelumnya. Oleh karena itu, pada kegiatan abdimas ini dilakukan pendampingan melalui optimalisasi pengelolaan BUMDes untuk mewujudkan keterampilan dan peningkatan kesejahteraan ekonomi di desa Patean Kecamatan Batuan kabupaten Sumenep.

\section{Metode Pelaksanaan}

Kegiatan pengabdian kepada masyarakat ini dilaksanakan pada tahun akademik 2020 di Desa Patean Kecamatan Batuan Kabupaten Sumenep. Kegiatan ini berfokus pada pendampingan budidaya lele oleh Badan Usaha Milik Desa Patean. Pendampingan terhadap BUMDes budidaya lele ini diharapkan dapat membantu menyejahterakan perekonomian desa yang bertujuan untuk mengelola potensi yang dimiliki desa sehingga dapat membantu mengembangkan jaringan ekonomi serta membuka lapangan kerja bagi masyarakat yang masih menganggur. Pelaksaannnya dilakukan dalam beberapa tahap, yaitu:

1. Tahap persiapan: secara umum, tahapan persiapan pada kegiatan pendampingan pengelolaan BUMDes budidaya lele di Desa Patean ini dimulai dengan mengidentifikasi para pengelola BUMDes melalui metode wawancara dan kuisioner tentang minat untuk membudidayakan lele. Observasi dan wawancara dilakukan pada tanggal 02-05 Maret 2020. Tim abdimas mengobservasi baik secara langsung maupun via online dengan mengamati kegiatan budidaya lele oleh BUMDes Desa Patean Kabupaten Batuan. Fase persiapan ini dilakukan secara daring melalui google meet pada tanggal 07-12 Maret 2020. Tim abdimas mengundang para pengelola BUMDes untuk mengikuti rapat rencana pendampingan. Pada rapat ini, tim abdimas memberikan pengarahan teknis terkait pendampingan yang akan diberikan. 
2. Tahap pelaksanaan: kegiatan pengabdian berlangsung pada tanggal 14-30 Maret 2021. Kegiatan pengabdian (pendampingan) ini dilaksanakan di Kantor Kepala Desa Patean Kecamatan Batuan Kabupaten Sumenep. Kegiatan pengabdian dilaksanakan dalam bentuk sosialisasi, FGD, dan pendampingan untuk membantu mengoptimalkan pengelolaan BUMDes melalui partisipasi masyarakat, memberikan pemahaman dan motivasi kepada masyarakat tentang pentingnya BUMDes dan dampaknya, dan membantu proses pengelolaan administrasi keuangan BUMDes seperti merapikan kegiatan transaksi yang berhubungan kegiatan BUMDes selanjutnya. Sosialisasi ke masyarakat dilakukan kepada para anggota karangtaruna, anggota PKK, dan masyarakat umum Desa Patean. Semua kegiatan dilakukan berdasarkan protokol kesehatan yang berlaku. Kegiatan pengabdian dilaksanakan selama 2 hari, yaitu pada tanggal 14, 15, dan 16 Maret 2021, kemudian dilanjutkan dengan pendampingan tambahan sekaligus evaluasi selama 2 bulan.

3. Tahap evaluasi: dilaksanakan setiap pekan selama 2 bulan dengan melihat perbandingan produktivitas sebelum dan setelah kegiatan pendampingan optimasi pengelolaan BUMDes budidaya Lele di Desa Patean kecamatan Batuan. Kegiatan ini dilakukan secara daring melalui laporan pengelolaan dan laporan akhir usaha di akhir setiap pekan.

\section{Hasil dan Pembahasan}

1. Hasil Observasi Terhadap Pengelolaan BUMDes Patean

Kegiatan pengabdian kepada masyarakat ini diawali dengan observasi terhadap BUMDes Al-Barokah yang didirikan oleh warga desa Patean kecamatan Batuan kabupaten Sumenep, yang wilayah pemerintahannya terdiri atas 3 Dusun, yaitu Dusun Patean Utara, Dusun Patean Selatan, dan Dusun Barat Sungai. Berdasarkan observasi yang dilakukan oleh tim Abdimas di Desa Patean, ditemukan permasalahan sebagai berikut, yaitu: 1. Sosialisasi terkait pentingnya kontribusi BUMDes budidaya lele sangat minim, sehingga menyebabkan pada minimnya partisipasi masyarakat dalam pengelolaan kegiatan BUMDES dan 2. Pengelolaan laporan keuangan BUMDes belum optimal.

2. Kegiatan yang Dilakukan

Sejak di tahap persiapan, tim Abdimas telah membentuk group WA yang terdiri dari pemerintah desa dan pengelola BUMDes. Pembentukan gup ini dikhususkan untuk membahas hal-hal yang terkait dengan kegiatan pengabdian. Adapun teknisnya dibahas secara online atau daring baik melalui WA group maupun aplikasi zoom meeting. Kegiatan pengabdian dilaksanakan sebagai berikut.

a. Sosialisasi kepada masyarakat terkait pentingnya keberadaan BUDMES budidaya Lele al-Barokah.

Sebelum kedatangan tim Abdimas, kegiatan di desa Patean masih terfokus kepada pengelola internal BUMDes dan kegiatan sosialisasi masih menjadi rencana awal yang akan diselenggarakan. Hal ini menyebabkan informasi terkait BUMDES budidaya lele di desa Patean relatif masih rendah dan masyarakat banyak yang tidak mengetahui fakta tentang keberadaan dan tujuan BUMDES yang ada di desa Patean. Merespon hal ini, tim Abdimas membantu memberikan solusi berupa kegiatan sosialisasi, FGD, dan pendampingan terhadap pengelolaan BUMDes budidaya lele al-Barokah. Kegiatan ini 
diselenggarakan untuk beberapa pihak, yaitu pengelola BUMDES budidaya lele, para anggota Karang Taruna, dan masyarakat umum Desa Patean termasuk di dalamnya Ibu-Ibu PKK. Dalam kegiatan sosialisasi ini, tim Abdimas menyampaikan beberapa paparan terkait peran pemerintah desa, bagaimana kewajiban dan tanggung jawab pihak pemerintah desa bagi kesejahteraan masyarakat, dan ajakan kepada masyarakat untuk ikut serta dalam pelaksanaan pemerintah dalam membangun ekonomi desa.

Sosialisasi mengenai BUMDes kepada masyarakat desa Patean agar masyarakat dapat memahami pentingnya keberadaan BUMDES budidaya lele bagi akses perekonomian desa ke depannya. Dalam hal ini, upaya sosialisasi dilaksanakan dengan turun secara langsung agar semua kebutuhan yang masih menjadi kekurangan pengelolaan BUMDes dapat dipahami oleh masyarakat dan dapat menarik simpati serta partisipasi mereka untuk turut serta dalam kegiatan pengelolaan BUMDes. Sebagai salah satu media atau sarana bagi masyarakat untuk mendapatkan suatu edukasi, kegiatan sosialisasi mengenai BUMDes budidaya Lele ini, diharapkan masyarakat yang telah memahami pentingnya kegiatan di BUMDes menjadi tertarik dan siap membantu.

Tim abdimas terus mensosialisasikan pentingnya pengelolaan BUMDes budidaya lele secara konsisten untuk mengatasi minimnya informasi yang sampai kepada masyarakat terkait kegiatan BUMDes budidaya lele di desa Patean ini. Dalam kegiatan sosialisasi ini, tim Abdimas juga memberikan pemaparan terkait pentingnya keberadaan BUMDes budidaya lele bagi masyakarat dan memberikan wawasan bahwasanya BUMDes saat ini menjadi peluang besar bagi masyarakat desa Patean terutama generasi anak mudanya dalam meningkatkan kesejahteraan ekonomi desa melalui optimalisasi pengelolaan BUMDes budidaya Lele di desa Patean, Kecamatan Batuan, kabupaten Sumenep (lihat gambar 1).

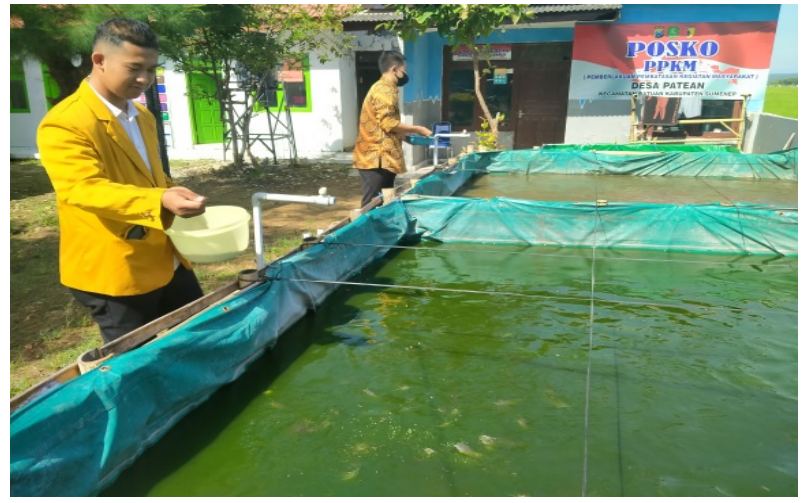

Gambar 1. Memberikan wawasan dan praktek tentang pengelolaan budidaya Lele kepada BUMDes al-Barokah.

Tim Abdimas juga memberikan motivasi kepada para pengelola BUMDes untuk lebih sering turun ke masyarakat dan memotivasi agar masyarakat lebih tertarik untuk berpartisipasi dalam kegiatan BUMDes, sehingga programprogram BUMDes ke depannya dapat lebih maksimal dan dapat membuka lapangan kerja bagi para pemuda. Dengan demikian, wujud dari pengelolaan BUMDes budidaya lele al-Barokah ini menjadi salah satu gerak orientasi yang mengarah pada pembangun ekonomi masyarakat deasa Patean yang sekaligus dapat mengurangi urbanisasi. 
Selain memberikan respon dan tanggapan yang sangat antusias, masyarakat secara umum juga menyepakati agar pemerintah desa Patean lebih memprioritaskan warganya dalam kepentingan apapun terutama di bilang kesehatan, perekonomian, dan administrasi pelayanan. Warga bahkan berharap akan terwujudnya masyarakat yang lebih makmur dan terpenuhi kebutuhankebutuhan hidupnya.

b. FGD untuk menarik minat dan partisipasi masyarakat terkait pengelolaan BUMDes budidaya Lele al-Barokah

Partisipasi masyarakat merupakan salah satu bentuk indikator yang dapat menunjang keberhasilan seluruh jenis kegiatan yang berlangsung di desa termasuk kegiatan BUMDes yang bergerak di bidang ekonomi. Namun masyarakat desa Patean tidak antusias dalam membantu keberlangsungan kegiatan BUMDES budidaya lele al-Barokah karena kurang atau tidak adanya pendekatan secara langsung oleh pengelola BUMDES kepada mereka. Kurangnya partisipasi masyarakat Desa Patean juga diakibatkan oleh rendahnya kesadaran individu warga yang menganggap bahwa pelaksanaan kegiatan BUMDES adalah tugas dan tanggung jawab pengelolanya saja. Rendahnya partisipasi masyakarat juga disebabkan oleh budaya urbanisasi yang menuntut kebutuhan hidup yang lebih tinggi.

Seorang warga lainnya juga menuturkan bahwa sebelum kedatangan tim Abdimas, keberadaan BUMDes budidaya lele belum menyentuh masyarakat secara menyeluruh, sehingga masyarakat sangat membutuhkan sosialisasi terkait hal ini untuk membantu membangun kesadaran mereka untuk turut berpartispasi. Ia juga menyampaikan harapan terbesarnya dalam pengelolaan BUMDes budidaya lele, yaitu menemukan pola inovasi yang membantu memaksimalkan pengelolaan BUMDes dan menggugah daya tarik masyarakat untuk ikut serta di dalam pengelolaannya.

Untuk mengatasi hal tersebut, tim Abdimas mengadakan FGD yang bertujuan untuk merubah pola pikir dan perilaku masyarakat agar menjadi teredukasi dan memahami makna pembangunan ekonomi berkelanjutan melalui kegiatan BUMDES budidayalele sebagai potensi yang sudah ada di desa mereka. Di dalam kegiatan FGD ini, tim Abdimas bertindak sebagai narasumber yang memaparkan tentang pentingnya keberadaan BUMDes budidaya lele bagi masyakarat, sebagai pendalaman dari kegiatan sosialisasi. Di antara paparan yng disampaikan yaitu bahwa keberadaan BUMDes telah memberikan peluang besar bagi masyarakat desa Patean dalam meningkatkan kesejahteraan ekonomi warga desa.

Dalam kegiatan FGD bersama para pegiat karang taruna yang sebagian besarnya adalah mahasiswa, salah seorang warga menuturkan harapannya untuk menjadikan Desa Patean sebagai tempat pengepul yang menyediakan bibit lele, sehingga tidak perlu bergantung pada pasaran bibit lele dari pulau Jawa, dan bisa membuka peluang bagi siapa pun warga yang siap bergabung dan berminat membudidayakan lele. Terkait hal ini, mereka mengungkapkan harapan untuk dapat membantu mensukseskan pengelolaan BUMDes dari segi teknologi dan pemasaran hasil panen budidaya lele. Tim Abdimas juga menghimbau kepada pengelola BUMDes untuk tetap turun ke masyarakat dan 
bersinergi dengan warga walaupun warga telah aktif berpartisipasi dalam pengelolaan BUMDes. Hal ini terjadi semata-mata agar terjadi hubungan mutualisme di antara mereka (lihat gamber 2).

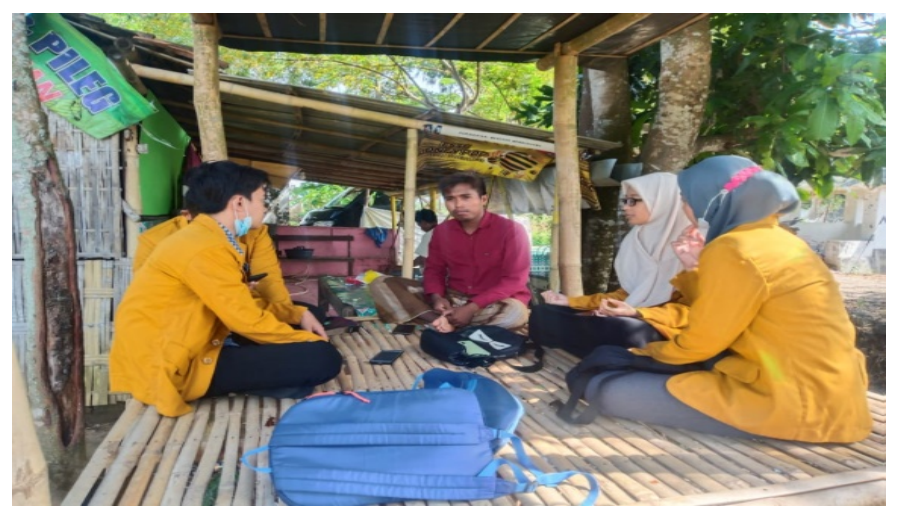

Gambar 2. Melaksanakan sosialisasi dan FGD dengan perwakilan pengelola BUMDes.

Dari pelaksaan sosialisasi dan FGD ini diharapkan berbagai potensi yang ada di BUMDES bisa terwujud berkat dukungan yang kuat dari masyarakat. Jika masyarakat mampu menjadi promotor dari setiap kegiatan yang ada, tentu pelaksanaan BUMDES budidaya lele itu dapat mendukung semua skala prioritas yang dibutuhkan. Hal ini dapat menjadi peluang dan upaya dalam meningkatkan pembangunan yang adil dan merata untuk masyarakat desa Patean.

c. Memberikan pendampingan dalam menyusun laporan keuangan secara digital

Pengelola adalah penggerak utama dalam kegiatan BUMDES budidaya Lele al-Barokah di Desa Patean. Namun di antara permasalahan pengelolaan BUMDES lainnya yaitu terkait dengan sistem laporan keuangannya yang sampai saat ini masih menggunakan sistem manual (buku catatan). Untuk memaksimalkan pemasaran hasil budidaya lele dan BUMDes budiaya lele di desa Patean ke depannya, dan agar BUMDES al-Barokah dapat berkembang dengan baik, maka tim pengabdi memberikan edukasi dan pendampingan dalam pembuatan laporan keuangan melalui Microsoft Excel. Hal ini dilakukan agar semua data transaksi dan neraca BUMDES dapat terdokumentasikan dengan sebaik-baiknya. Pelatihan dan pendampingan ini dilaksanakan agar para pengelola BUMDes tidak lagi menggunakan sistem manual (buku catatan) dalam menyusun laporan keuangan.

Dengan demikian, pengabdian kepada masyarakat kali ini telah sesuai dengan fokus, yaitu untuk meningkatkan kesejahteraan ekonomi desa melalui optimalisasi pengelolaan BUMDes Al-Barokah yang bergerak di bidang budidaya lele di desa Patean. Pengabdian ini diharapkan dapat memberikan manfaat positif baik bagi Badan Usaha Milik Desa (BUMDesa) maupun Pemerintah Desa Patean agar dapat mengevaluasi program, meningkatkan pelayanan demi terwujudnya kesejahteraan sosial masyarakat, dan memenuhi kebutuhan tenaga kerja yang sesuai dengan keahlian warganya.

Di antara hasil dari sosialisasi, FGD, dan pendampingan yang telah dilaksanakan oleh tim abdimas dalam meningkatkan kesejahteraan ekonomi desa melalui optimalisasi pengelolaan BUMDes budidaya Lele al-Barokah di desa Patean ini adalah: 1. 
Terbentuknya peluang bisnis aneka kuliner olahan lele pada kelompok PKK; 2. Terwujudnya laporan keuangan BUMDES budi daya lele secara digital (computerized), dan 3. Inovasi pengelolaan BUMDes budidaya lele yang meningkat secara perlahan namun signifikan dan dapat membantu meningkatkan kesejahteraan ekonomi desa. Para pengelola BUMDes juga dapat memfasilitasi para anggota PKK dalam mengembangkan produk BUMDes dengan memproduksi hasil budidaya lele menjadi aneka olahan kuliner seperti abon lele, keripik lele, kerupuk lele, dan lain sebagainya.

Hambatan dan kendala yang ditemukan oleh tim Abdimas selama pelaksanaan pengabdian masyarakat ini adalah hambatan partisipasi. Dua faktor yang mempengaruhi partisipasi masyarakat yaitu faktor internal seperti latar belakang, kurangnya motivasi, pengetahuan, dan pengalaman individu; dan faktor eksternal seperti kondisi sosial, politik, ekonomi, dan budaya. Sosialisasi dan FGD penting dilakukan karena mengacu pada proses belajar individu yang akan mengubah pola pikir dari tidak tahu menjadi tahu dan memahami tentang lingkungannya. Termasuk dalam hambatan ini adalah konflik antar beberapa individu yang kontra dengan pemerintah desa. Hambatan berikutnya adalah masih terbatasnya keterampilan sumber daya manusia dalam pengelolaan BUMDes, baik dari aspek leadership, manajerial, kreativitas, ketrampilan, dan lainnya. Hambatan lainnya yaitu pandemi COVID-19 dan pemikiran masyarakat yang masih tradisional dalam memandang permasalahan yang mereka hadapi.

berdasarkan hambatan-hambatan di atas, maka solusi yang ditawarkan tim abdimas untuk mengatasi hambatan tersebut adalah: 1. Memberikan sosialisasi dan pemahaman tentang BUMDes dan semua program kerja pemerintah desa, agar tidak terjadi kesalahpahaman oleh warga terhadap kebijakan BUMDes yang ditetapkan oleh pemerintah desa; 2. Memfasilitasi pelaksanaan FGD agar warga memahami pentingnya partisipasi dalam pengelolaan BUMDes untuk meningkatkan kesejahteraan perekonomian desa; dan 3. Melakukan pendampingan dan evaluasi terhadap pengelolaan BUMDes al-Barokah, dan memotivasi para pengelola agar terus melakukan inovasi dan skill-up grading, agar pengelolaan BUMDes menjadi lebih maju dan berkontribusi dalam meningkatkan perekonomian desa Patean.

\section{Kesimpulan}

Berdasarkan evaluasi dari kegiatan pendampingan optimalisasi pengelolaan BUMDes budidaya lele di desa Patean Kecamatan Batuan, maka dapat disimpulkan bahwa:

1. Keberadaan BUMDES budidaya lele Al-Barokah saat ini telah menjadi lembaga yang memiliki peran dalam memperkuat perekonomian berdasarkan potensi desa Patean. Namun demikian, para pengelola BUMDes dan masyarakat pada umumnya masih membutuhkan pendampingan dalam mengoptimalkan pengetahuan, inovasi, dan administrasi guna memaksimalkan kontribusi mereka terhadap keberlangsungan kegiatan BUMDES dan meningkatkan produktivitas usahanya.

2. Kegiatan pendampingan sangat dibutuhkan bagi para pengelola BUMDES budidaya lele Al-Barokah dalam menarik minat masyarakat untuk berpartisipasi dalam program-program BUMDES sehingga terjadi peningkatan kesejahteraan ekonomi desa.

\section{Referensi}

Dwiningwarni, S. S., \& Amrulloh, A. Z. (2020). Peranan Pengelolaan Dana Desa Untuk Meningkatkan Pendapatan Masyarakat Di Jombang Jawa Timur. EKUITAS Jurnal 
Ekonomi Dan Keuangan), 4(1), 1-20. https://doi.org/10.24034/j25485024.y2020.v4.i1.4128.

Firdaus, R. (2020). Peran Badan Usaha Milik Desa (BUMDES) Dalam Pemberdayaan Ekonomi Masyarakat Desa Manding Laok Kec.Manding Kab.Sumenep. Jurnal Inovasi Penelitian, 1(7), 1387-1394. https://stp-mataram.ejournal.id/JIP/article/view/235

Friscilla, M., Arifin, J., \& Noor, M. (2020). Partisipasi Masyarakat Pada Program Pos Pelayanan Terpadu (Posyandu) Di Desa Ampari Kecamatan Awang Kabupaten Barito Timur. Administrasion Public Dan Administrasion Bisnis, 3(1), 275-294.

Larasati, D. C. (2019). Partisipasi Masyarakat Dalam Mengembangkan Taman Posyandu Sri Rejeki Di Kelurahan Kotalama Kecamatan Kedungkandang. Reformasi, 9(1), 55. https://doi.org/10.33366/rfr.v9i1.1323

Pradana, A. C., \& Ma'ruf, M. F. (2021). Pembinaan dan Pengawasan Penyelenggaraan Pemerintahan Daerah Dalam Pengelolaan Keuangan Pemerintah Desa. Publika, 9(1), 285-294. https://ejournal.unesa.ac.id/index.php/publika/article/view/37841

Puspaningrum, I. I., \& Kurniawati, D. (2019). Meningkatkan Peran Bumdes Sebagai Penggerak Ekonomi Masyarakat Desa Di Desa Ellak Daya Kecamatan Lenteng. Jurnal ABDIRAJA, 2(2), 24-29. https://doi.org/10.24929/adr.v2i2.754

Raka, I. D. N., Widnyana, I. W., \& Suparsa, I. N. (2018). Biochar Sebagai Input Dalam Pengelolaan Tanaman Manggis Di Desa Jelijih Punggang. Abdimas: Jurnal Pengabdian Kepada Masyarakat, 10(02), 20-25. https://doi.org/10.36412/abdimas.v10i02.362

Srirejeki, K., Faturahman, A., Warsidi, W., Ulfah, P., \& Herwiyanti, E. (2020). Pemetaan Potensi Desa untuk Penguatan Badan Usaha Milik Desa dengan Pendekatan Asset Based Community-Driven Development. Warta LPM, 23(1), 24-34. https://doi.org/10.23917/warta.v23i1.8974

Wahyuningtyas, I. K. (2021). Peran Strategis Bumdes (Badan Usaha Milik Desa) Dalam Pemberdayaan Ekonomi Desa. Jendela Inovasi Daerah, 4(1), 91-101. http://jurnal.magelangkota.go.id/index.php/cendelainovasi/article/view/95

Yudiardi, D., Bin Hasyim, S., Kunci, K., \& Usaha Milik Desa, B. (2020). Sosialisasi Pengelolaan Badan Usaha Milik Desa (BUMDes) Cisangkal Kecamatan Cihurip Kabupaten Garut. Budaya Dan Masyarakat, 1(1), 16-19. www.lanmas.fisip.uniga.ac.id 